Research Articles

\title{
Three Sticks Wines: Digital Marketing, Branding, and Hospitality During a Crisis
}

\author{
Matthew Coyne ${ }^{1}$ \\ 1 Sonoma State University \\ Keywords: wine branding, hospitality, digital marketing, supply chain management, co-branding, co-promotion, crisis leadership \\ https://doi.org/10.26813/001c.22071
}

\section{Wine Business Journal}

Vol. 4, Issue 2, 2020

\begin{abstract}
This study examines a luxury winery located in Sonoma County, Three Sticks Wines, as it navigated a novel crisis-laden market created by the Covid-19 pandemic. The drastic effects on the industry as a whole and those specific to the premium segment are explored. Strategy to mitigate business displacement is analyzed and developed by the author to present a multi-faceted augmentation of marketing tactics. Areas of focus include digital marketing, co-branding, co-promoting, vineyards as marketing entities and wholesale allocation strategy. The case draws from leading academic research in strategy, consumer behavior, and digital marketing. A conclusion is reached that the winery should consider the range of tactics individually or jointly to maximize its marketing effort commensurate to business needs and shifting market conditions.
\end{abstract}

Price Family Vineyards' (PFV) President and Chief Financial Officer, Thomas V. Bonomi, Jr., guided Three Sticks Wines to growth, until the building danger of COVID-19 triggered a statewide "shelter-in-place" mandate at midnight on March 20, 2020. Suddenly, the winery's Sonoma, CA, tasting room, the Adobe, which had been integral to the brand's success, was closed indefinitely. Bonomi needed to quickly reassess his strategy.

Similar lockdowns rapidly ensued throughout the country. The supply line for drinking at restaurants and other venues across the country was cut off, almost like someone closed a valve. The mandate closed tasting rooms and other direct-to-consumer (DTC), on-premise businesses. In an instant, the most prolific brand-building and revenue-generating strategic asset for archetypical luxury producers was shut down.

Bonomi swiftly led a strategic shift to bolster brand building. First, the winery launched virtual tastings modeled to replicate the experience at the Adobe. Consumers would acquire the wine and taste at home guided by a virtual host from the Adobe. Second, Bonomi reinvigorated their social media effort by increasing content creation. A virtual event program, "Three Sticks Together," was created featuring live streams and other content; it was uploaded to YouTube and social media platforms. It included virtual concerts emceed by vintner Bill Price, wine in hand. His unique contacts, born through the goodwill of philanthropy, were leveraged to secure Grammy award-winning musicians.

The initiatives showed some signs of success. Direct-toconsumer shipping orders across the country spiked in the immediate and short-term lockdown aftermath, which fed timely high margin revenue to luxury producers, including Three Sticks. With the new prism of a crisis-laden market coming into focus, Bonomi confronted the questions of a new strategic reality:
- How should the winery be positioned in the novel market?

- How has the route to market been effected?

- How can the Three Sticks brand continue to be discovered with the frequency and impact that has driven growth?

\section{THE U.S. WINERY INDUSTRY AND MARKET IN 2020}

As of January 2020, of the 10,472 wineries operated in the United States, California led the count by far with 4,613. Washington and Oregon each housed over 800, and New York and Texas each had over 400 . The number of wineries grew consistently from 6,357 in 2009, adding almost 700 in 2020 . Of the 72 domestic wineries producing over 500,000 9L cases, the top three firms had a combined 34.8 percent market share. These 72 wineries constituted less than one percent of all wineries in the industry. The vast majority of wineries, 81 percent, produced 5,000 cases or less (Statistics - Wines Vines Analytics, n.d.). Gallo controlled the largest market share at 19.7 percent, followed by the Wine Group at nine percent, and Constellation at 6.1 percent. Major brands in 2019 owned by these firms, include Gallo's Barefoot at over USD 668 million in sales, Constellation's Woodbridge by Robert Mondavi at over USD 346 million, and the Wine Group's Franzia Box wine at over USD 345 million (McMillan, 2020, p. 34). In 2018 sales in the U.S. wine market grew to 408 million 9L cases, which represented USD 70.5 billion in value (Wines Vines Analytics, 2019).

The domestic market had evolved primarily into two disparate tiers. In 2020, the top four producers earned an estimated 38.1 percent of industry revenue, based in large part on value driven brands (Lombardo, 2020). These larger producers leveraged economies of scale to gain cost efficiencies, strategic clout with large distributors, superior busi- 


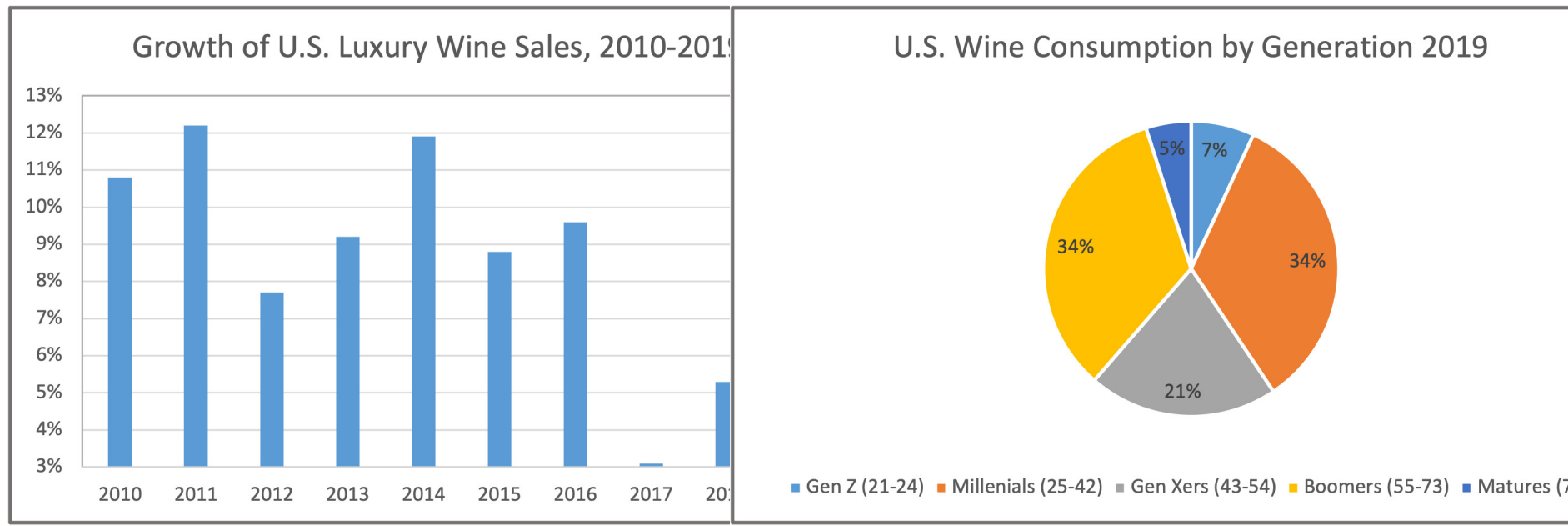

Exhibit 1: U.S. Luxury Wine Sales, 2010-2019

Source: Silicon Valley Bank, State of the Wine Industry Report 2020.

ness intelligence, and the repurchase benefits of the double-jeopardy principle and the duplication of purchase law. Empirical evidence indicates these principles are highly influential for sales of fast-moving consumer goods (FMCG) (Dawes, 2008). Smaller wineries competed with quality control and limited releases of high-priced wines in order to tout both their quality and exclusivity. However, not only was the market saturated with smaller brands, but with brands using these tactics. These tactics followed a differentiation strategy. Some luxury and larger producers opted for a distinction strategy, characterized by highly salient packaging with the aim of catching the attention of shoppers. Luxury producers employing a differentiation strategy needed to convey their message of discernable difference. Consumers in the U.S. market may not be able to appreciate and self-verify the relative value of an incremental difference in quality. So, if a marketer seeks to convince consumers that their USD 45 bottle is equally as good as the USD 50 competitors in the category, the consumer will struggle to assess that claim. Whether the bottle is equal in quality to the USD 50 bottle, and thus offers USD 5 in savings, is challenging to determine by tasting.

Before the brunt of COVID-19's impact, U.S. wineries, producing under 5,000 cases, competed intensely amidst high levels of saturation and fragmentation set against positive but slowing growth indicators.

\section{Trends in U.S. premium wine segment 2020-pre- crisis}

As seen in Exhibit 1, the premium wine segment of the U.S. market grew consistently and quickly since 2010 with 2019 over seven percent.

In recent years domestic wines had controlled approximately two thirds of the market share as the average bottle price climbed to USD 14.85 in 2019. Exhibit 2 depicts this market landscape.

Premiumization had been suggested as the cause for the increasing average bottle price. This simplistic assumption, however, may misconstrue the trends which truly caused the rise in average price. Price may have risen due to con-

\section{Exhibit 3: U.S. Wine Consumption by Generation}

Source: Dr. Liz Thach, MW, 2020.

sumers progressing to higher average prices. However, price may have also increased due to a lack of new consumers entering the wine category. Typically, consumers begin with lower priced wine, so without an influx of new consumers, the average price would rise. Both phenomena are likely to be occurring to some extent. Winery leaders may be unduly comforted by the rising average value if the reduction in category entrance was not considered as well. The importance of catering to younger consumers and not relying excessively on baby boomers was evidenced by the generational market participation illustrated in Exhibit 3.

Recent studies showed millennials were quite different than baby boomers. Millennials were more technologically savvy and valued innovation, fun, collaboration, and diversity. Wineries had a significant opportunity to connect their brand with millennial consumers digitally. Five of six millennials embraced brands on social media, and 63 percent updated themselves using these platforms. In fact, 46 percent of online purchases were made after a recommendation or other influence from social media. A significant counter factual regarding the value of the demographic existed: the majority of young people had less than USD 1,000 in their savings accounts, of which a significant number had no savings (Desjardins, 2019). However, luxury producers only needed to reach a fraction of millennials and successfully progress them through the Awareness, Interest, Desire, Action, Sale (AIDAS) model to achieve throughput objectives. The cultural inclinations espoused above were widespread and carried significant influence with much of the generation; whereas a significant portion of the demographic had more than USD 1,000 in savings and could afford to spend USD 200-500 annually with a luxury wine brand. The veracity of this statement may have waned to an extent in regard to the immediate lockdown aftermath given the widespread obstructions from business operations. However, the phenomenon was still expected to occur over time. As the generation matures, disposable income was expected to increase while the loss of baby boomers from the category would occur incrementally. The two phe- 
Exhibit 2: Value and Volume of U.S. Wine Market, 2016-2019

\begin{tabular}{rrrrrr}
\hline Year & \multicolumn{1}{c}{ Volume } & \multicolumn{1}{c}{ Value - Domestic } & \multicolumn{1}{c}{ Value - Imports } & \multicolumn{1}{c}{ Domestic Market Share } & Average Price \\
\hline 2016 & 397.2 & $\$ 39.8$ & $\$ 20.2$ & $66.33 \%$ & $\$ 12.59$ \\
2017 & 401.7 & $\$ 41.8$ & $\$ 20.9$ & $66.67 \%$ & $\$ 13.01$ \\
2018 & 405 & $\$ 46.2$ & $\$ 23.5$ & $66.28 \%$ & $\$ 14.34$ \\
2019 & 406.4 & $\$ 47.9$ & $\$ 24.5$ & $66.16 \%$ & $\$ 14.85$ \\
\hline
\end{tabular}

*Volume in millions of 9L units

"Value in USD billions

Source: Wine Institute, Dr. Liz Thach, MW.

nomena both magnify the demographics' relative importance to the market.

Consumers often discovered new alcohol brands in restaurants and other establishments where alcohol was consumed on-premise. Brand introductions were made by wine experts, sommeliers, or other staff who made many impactful and positive first impressions. The lockdowns disrupted this process by cutting off business to on-premise retailers. On-premise consumption statistics illustrated the magnitude of the challenge to compete for new consumers against the beer and spirits categories. In 2019, wine only accounted for 17 percent of sales behind spirits at 37.8 percent and beer at 45.2 percent (Ozgo, 2020).

Direct-to-consumer business represented 60 percent of sales for the average American winery in 2019. Of these DTC sales, 28 and 23 percent were generated by the tasting room and wine club sub-categories, respectively. The wholesale channel contributed approximately 34 percent to revenue. Sales contributions from the DTC channel increased in 2016 to approximately 60 percent where it has remained until an uptick at the onset of government mandated lockdowns in March 2020. Sales volume growth slowed from 2016 while value continued to grow, albeit at an incrementally waning rate (McMillan, 2020, p. 35).

\section{Bulk wine market}

The U.S. bulk wine market was heavily oversupplied leading into the 2020 harvest, which was expected to be average in yield. June 2020 was one of the most active for the California bulk wine market in recent years. Bulk wine brokers observed lower asking prices for grapes and bulk wine, increased inventory of high-quality grapes, smaller inventories among wineries, and the unexpected spike in off-premise sales growth. The increase in on-premise sales spurred some producers to purchase more bulk wine to satisfy increased demand. Purchasing activity picked up in March and April initially in response. The potentially temporary increase in sales alleviated the oversupply pressure to an extent, yet major oversupply persisted. Coastal bulk sales were slow and only matched the price typically paid for the California appellation equivalent (Ciatti Global Wine \& Grape Brokers, 2020). California bulk wine pricing is detailed in Exhibit 4.

\section{Import competition}

International competition from European producers, especially Italy and France, was an established feature of the
U.S. market. However, newer competition from "New World" wine producers from outside of Europe increased competitive pressure further. New World importers offered highly competitive price points and stylistic similarities to domestic offerings. In 2018, imported wines accounted for 33 percent of the value and 26 percent of the volume of wine sold in the U.S. (Wines Vines Analytics, 2019). The primary import rivals are presented in Exhibit 5.

\section{Industry impact from Covid-19}

Market projections and prognostication proved difficult as the lingering and uncertain nature of the pandemic took a comprehensive toll on the industry. The impact was negative, with losses for all domestic wineries estimated at USD 5.9 billion with California accounting for USD 4.22 billion of that amount. The "return to normal" for tasting rooms and restaurants, in terms of business development, was not expected until 2023 (Wine Communications Group, 2020). Reduced opportunity for ingratiating brand discovery via direct efforts and trade partners meant producers needed to find alternative ways of getting their message out in a memorable way. Many small wineries had an "online store" on their website and social media pages. However, vigorous effort was needed to make up for the lost brand growth opportunities.

\section{Harvest and labor outlook in 2020}

The 2020 harvest in California was expected to be slightly below average in volume. The severe oversupply issue was expected to leave significant fruit hanging unpicked. The vintage appeared to show signs of promise although aggregate quality was not yet determined by July 2020.

Labor was a significant concern for vineyard operations. Many of the harvest workers in the past originally came from Mexico or other Latin American nations without the benefit of U.S. citizenship. The federal government's enforcement-heavy policy surrounding immigration caused some to leave the country. Others were attracted to higher paying jobs in the construction and cannabis industries which were expanding in the region. Labor costs were expected to increase to accommodate COVID-19-related safety measures. The Wine Institute provided a link to a comprehensive handbook on how to safely augment operations (California Association of Winegrape Growers et al., 2020). 
Exhibit 4: California Bulk Wine Price per Liter, July 2020

\begin{tabular}{|c|c|c|c|c|c|}
\hline & \multicolumn{2}{|c|}{ Range } & & \multicolumn{2}{|c|}{ Range } \\
\hline White Blend & $\$ 0.90$ & $\$ 0.99$ & Red Blend & $\$ 0.79$ & $\$ 1.05$ \\
\hline Chardonnay & $\$ 1.20$ & $\$ 1.59$ & Cabernet & $\$ 1.09$ & $\$ 1.85$ \\
\hline Pinot Grigio & $\$ 1.25$ & $\$ 1.59$ & Merlot & $\$ 1.12$ & $\$ 1.38$ \\
\hline Muscat & $\$ 1.07$ & $\$ 1.45$ & Pinot Noir & $\$ 1.40$ & $\$ 1.85$ \\
\hline & & & Syrah & $\$ 1.09$ & $\$ 1.58$ \\
\hline
\end{tabular}

Source: Ciatti Global Market Report, July 2020.

Exhibit 5: Wine Importers to the U.S. Market, 2018

\begin{tabular}{|c|c|c|c|c|c|}
\hline & Italy & France & Spain & New Zealand & Australia \\
\hline Volume Produced & 54.8 & 48.6 & 44.4 & 3 & 12.9 \\
\hline Value of Vintage & $\$ 8,762.5$ & $\$ 12,555.5$ & $\$ 1,421.9$ & $\$ 3.6$ & $\$ 792.9$ \\
\hline Total Value Exported & $\$ 7,324.4$ & $\$ 10,965.2$ & $\$ 3,124.2$ & $\$ 1,216.9$ & $\$ 2,084.8$ \\
\hline Value Imported & $\$ 1,332.4$ & $\$ 1,251.7$ & $\$ 193.7$ & $\$ 465.1$ & $\$ 293.9$ \\
\hline
\end{tabular}

*Volume in millions hectolitres

*Value in USD millions

Sources: Wine Australia 2018, NZ Winegrowers, OIV 2020, PRB 2018.

Exhibit 6: American and Global Wine Industry Dimensions

\begin{tabular}{lrrr}
\hline Dimension & U.S. & Global & Rank \\
\hline Vineyard Area & 0.44 & 7.45 & 6 th \\
Grape Production & 6.9 & 77.8 & 3 rd \\
Wine Production & 23.9 & 292 & 4 th \\
Market Value (USD) & $\$ 72.4$ & $\$ 304$ & 1 st \\
Consumption & 33 & 246 & 1 st \\
Per Capita Consumption & 1.67 & 2.6 & 44 th \\
\hline
\end{tabular}

*Vineyard Area \& Grape Production in millions hectares \& tonnes, respectively.

"Wine Production and Consumption in millions hectoliters, per capita in liters.

Source: OIV 2020, Thach 2020, McGregor 2020, NationMaster.com.

\section{Global market trends}

In 2018, 292 million hectoliters of wine were produced globally of which 246 was expected to be consumed. The oversupply issue started with the large 2018 vintage and was exacerbated by slowing of growth in global consumption. The U.S. was still the most valuable wine market in the world, although the growth and potential in China's market made it a crucial channel for French and other European exporters. New Zealand was a major export success, rising another eight percent in 2020 to an export value of USD 1.28 billion. Although wine consumption slowed, the average value of wine shipments increased. The millennial generation embraced wine in the U.S. to a greater extent than their counterparts in Europe, who trended towards spiritbased beverages and other options (International Organisation of Vine \& Wine Intergovernmental Organisation, 2019). Exhibit 6 provides a snapshot of the global industry with the U.S. industry contextualized against it.

\section{Climate change}

The global challenge of a warming Earth threatened and augmented the cultivation landscape for producers. The first key affect was the global vineyard map expanded with plantings in areas traditionally considered too cold. Vineyardists planted at higher elevations to mitigate the temperature increase. Some new vineyards were planted at aspects with reduced sunlight. Decreased predictability in weather was another major issue to contend with (Asimov, 2019). Some regions considered new varietals. Bordeaux's adoption of new grapes within their various regional and classified growth appellations was a high-profile example (Mercer, 2019).

\section{Strategic possibilities for smaller wineries}

Smaller wineries had various strategic options to consider. One strategy was creating a new brand that would be well priced and otherwise positioned for the new market conditions. When pursuing this strategy, a winery could 
separate the new brand from the existing one, although some cases may have called for creating a second brand that references the first. Woodbridge by Robert Mondavi was a prominent example of tying the new brand to the existing one overtly. Accessing the market via distribution would have been very difficult for small producers. Major distributor consolidation led to a dramatic "hourglass effect," bottlenecking the market between the copious producers and consumers. Additionally, the benefits of economy of scale realized by larger producers constituted a competitive advantage that smaller wineries had to overcome. To largely negate the advantage, firms could have narrowed their market focus. A winery could thereby gain a larger share of that market segment, and thereby realize the increased rate of repurchasing suggested by the double-jeopardy principle and duplicate purchase law (Dawes, 2008).

Smaller wineries could have marketed unique and limited release wines, which would gain value by virtue of their exclusivity. Building on this strategy, wineries could have offered exclusive or preferred access to boutique wine retailers to move product and benefit from the frequency of brand introductions and purchases. In the AIDAS model, clientele of on-premise retailers would have already been in the desire or action phases. Getting past awareness and interest as a luxury producer could have been difficult. Considering the oversaturation in the premium segment and the exacerbation of the hourglass effect spurred by the pandemic, producers needed to secure new or build upon existing routes to market.

\section{PRICE FAMILY VINEYARDS AND THREE STICKS WINES \\ Bill Price and company history}

Bill Price was a passionate vintner and member of the wine industry with significant strategic experience in vineyards and winery operations. Price went to high school in Hawaii where he developed a love of surfing. His nickname from those years, "Billy Three Sticks," was the inspiration for the Three Sticks brand name.

Price first invested in the wine sector in 1995. At the time, the private equity firm he had co-founded, Texas $\mathrm{Pa}$ cific Group (TPG), purchased the Beringer Winery in Napa Valley. In 1997, he purchased the Durell Vineyard in Sonoma County from Ed Durell. In 2002, Price and his wife, Eva, founded Three Sticks Wines. In 2007, Price decided to leave TPG and focus full time on the wine industry. Price remembered:

\footnotetext{
I longed to return to something that brought me back in touch with the natural world on a regular basis. Working with exceptional vineyard properties to grow the very best grapes and partnering with talented winemakers was what I was passionate about. (Wine Communications Group, 2016b)
}

Later in 2007, Price was approached by Steve Kistler and invested in a controlling interest in his critically acclaimed brand. Kistler founded Kistler Vineyards in 1978, where in his role as winemaker, the brand gained esteem in part from consistently high scores among ratings from major wine critics. Price employed a partnership strategy with wine-

makers in recruiting them to join his winery operations. Winemaking that carried a discernable stylistic ethos anchored in expression of the land was sought as winery operations developed across brands.

In a press release from March 2011, Price announced restructuring within the company including several key promotions. He explained the strategic vision:

Classic Wines and Price Family Vineyards were in a
strategic growth phase...We were expanding our port-
folio of world-class vineyard sites and wine brands
through a highly selective process of acquisition and
development. We were fortunate to have a team of tal-
ented managers who were able to step up to new re-
sponsibilities as we expanded our operations. Tom,
Steve, and Rob were a proven team with the experience
to ensure our ongoing success. (Wine Communications
Group, 2011)

In 2009, Price led the Vincraft Group's investment in Kosta Browne Winery. In 2011, the group purchased Gary Farrell Winery. Both wineries sourced grapes from Price Family Vineyards and outside sources. The vineyard portfolio grew notably in 2013 with the acquisition of the Gap's Crown Vineyard in the Petaluma Gap appellation in Sonoma County. Kosta Browne Winery was sold in 2015. That same year, Price founded Head High Wines with winemaker and fellow surfer Sam Spencer. The brand was primarily composed of estate fruit with some outside sourcing and was sold primarily via on-premise retailers. In 2016, Head High secured Oahu North Shore-based big wave surfer, Andy St. Onge, as a brand ambassador (Wine Communications Group, 2016a).

The PFV brand portfolio in 2020 included Three Sticks Wines and Head High and controlling interests in Gary Farrell Winery and Kistler Vineyards. Vineyard holdings grew to six by 2020 containing approximately 122 planted hectares (301 acres) of high-quality vineyards in Sonoma County. Acquisition and planting projects accounted for the firm's other four smaller vineyards: Alana, One Sky, Walala, and William James.

The vineyards yielded on average from 180 to 200 tonnes each vintage. Grapes were also sold to other brands, including: Patz \& Hall, Chasseur, Chateau St. Jean, Loring, Tor, Lioco, Realm, Kosta Browne, and Dunstan (T. Bonomi \& P. Behan, personal communication, July 2, 2020). The complete vineyard portfolio is outlined in Exhibit 7.

\section{Thomas Bonomi, Jr.}

Tom Bonomi had succeeded as an executive in the wine sector with notable roles such as a managing director with Global Wine Partners. In 2007, he joined with Bill Price to found Classic Wines. He led the company to focus on strategic growth opportunities to surmount key milestones in its evolution. Strategy surrounding the investment into Kistler Vineyards and the subsequent proliferation of its Chardonnay portfolio was executed during Bonomi's tenure.

The Kosta Browne acquisition in 2009 was a particularly important event in which Bonomi's expertise contributed to a well-timed transaction. The acquisition preserved the founding team of Dan Kosta, Michael Browne, and Chris Costello, including their existing strategic contributions 
Exhibit 7: Vineyard Assets, Sonoma County

\begin{tabular}{crrr}
\hline Vineyard & Pinot & Chardonnay & Other \\
\hline Gap's Crown & 42.9 & 13 & 8.2 \\
Durell & 20.2 & & \\
Walala & 6.9 & 1.2 \\
One Sky & 3.2 & 1.4 \\
Alana & 0.8 & & 35.8 \\
William James & 2.8 & 3.9 & 8.9 \\
TOTAL: & 76.8 & & \\
\hline
\end{tabular}

*Area in hectares

Source: Prepared by author with information from Three Sticks Wines.

and respective equity positions. The 2009 Sonoma Coast Pinot Noir was later crowned Pinot Noir of the Year in 2011 by Wine Spectator. The magazine's website continued to host multiple videos dedicated to the brand featuring senior editor James Laube (Laube, 2011). The Gap's Crown Vineyard comprised a portion of the award-winning wine, and in 2013 Bonomi followed up by acquiring the esteemed site for PFV. He presided over the construction of a state-of-theart winery and estate vineyard acquisition before the brand was sold in 2015 . The profit was atypically large by industry standards.

Bonomi continued to lead as president and CEO of Price Family Vineyards and Estates in the summer of 2020. His leadership led the larger Price group and Three Sticks Wines to successful growth and profitability in the face of a novel pandemic. The severity of new market conditions and disruptions, however, were addressed utilizing Bonomi's expertise to keep the business's successful inertia from slowing.

\section{THREE STICKS WINES}

Winemaker Bob Cabral was engaged to employ his vision and create the Three Sticks wine portfolio. The brand was created featuring wines designated by appellation or the vineyard site. All grapes were sourced exclusively from the estate vineyards. The winery made approximately 10,000 9L cases of wine over the last several vintages. Wine was sold directly to the consumer primarily via tastings and experiences at the historic Adobe in Sonoma. A significant allocation of specific wines was offered through the retail market (C. Mattson, personal communication, July 23, 2020).

\section{The historic Vallejo-Casteñada Adobe}

The historic Vallejo-Casteñada Adobe was purchased in November 2012. Bill and Eva Price assembled a group of local architects, designers, contractors, and archeologists to protect the Adobe's physical integrity and preserve the components of greatest historical significance. Internationally known interior designer Ken Fulk was hired specifically for his aptitude in integrating elements from past and present into his designs. His body of work was significant; most notably, his commission in 2020 to redesign Manhattan's iconic Chrysler Building's Cloud Club evidenced his continued prominence (Luckel, 2020).

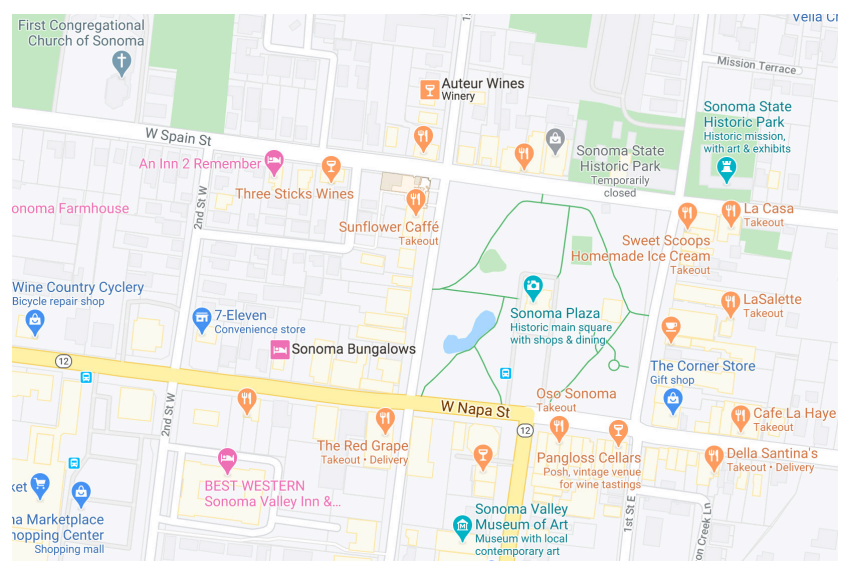

Exhibit 9: Adobe's Location Near the Sonoma Plaza

Source: Googlemaps.com

The restoration revealed what was identified as a refuse site, estimated to date from 1860-1880. The City Historian of Sonoma, George McKale, was brought in to oversee the excavation while the Three Sticks team provided the labor. Select discoveries from the dig were made available for guests to see and hold while visiting the Adobe. The historical preservation efforts were well justified, as is illustrated by the structure's timeline detailed in Exhibit 8.

The restoration was completed, and Three Sticks at the Adobe opened up for visitors in November 2014. The Adobe created positive and impactful brand introductions and experiences. Winery hospitality set in a historic Adobe structure was a unique combination by itself. Adding provocative design elements by a famous designer was an attraction consumers had come to expect in engaging wineries.

A map of the Adobe's location near the Sonoma Plaza is provided in Exhibit 9.

\section{Mission statement}

"We believe in stewardship of the land, the vineyards, and the people. We are for real connections, real history, real wines; experiences you will never forget" (Three Sticks, n.d.-b).

The winery followed its mission statement across departments and operations. The vineyards were sustainably farmed in consideration of the long-term health of the local 
Exhibit 8: Vallejo-Casteñada Adobe

\begin{tabular}{|c|l|}
\hline 1842 & Constructed by Captain Salvador Vallejo, infamous brother of beloved General Mariano Vallejo. \\
\hline 1947 & Gregory \& Harriet Jones purchased the property, which they called “La Casita," and launched into a major restoration. \\
\hline 1997 & $\begin{array}{l}\text { Mrs. Jones' estate sold The Adobe to her dear friends Robert \& Leslie Demler who meticulously cared for the building for } \\
\text { the next 15 years. }\end{array}$ \\
\hline 2012 & $\begin{array}{l}\text { Bill \& Eva Price purchased The Adobe from the Demlers for Three Sticks in November 2012, 170 years after its original } \\
\text { construction. }\end{array}$ \\
\hline
\end{tabular}

Source: ThreeSticksWines.com

wildlife and natural environment. Vineyard plantings were limited in order to preserve nature's ability to thrive. The various properties allocated significant area to preservation efforts, including allowance for corridors of movement.

The winery looked after its people by providing a positive environment and continued training and support. The website featured many of the team members and their biographies. Wineries in many cases will only have a few biographies on their website, which depict the owners and top leaders.

The wine itself was made with Bob Cabral's directions and his self-espoused "minimal intervention" focus (Three Sticks, n.d.-a). Expressing a winemaking stylistic identity while revealing the uniqueness of the vineyard embodied the goals of real wines and responsible stewardship.

The winery followed the historical component of its mission by offering tastings set in the Vallejo-Casteñada Adobe, where guests could absorb the historical content and become a part of the story.

\section{Hospitality operations}

The winery hosted various tastings, experiences, and events at the Adobe. Consumers were welcomed by appointment. The range of offerings before the pandemic materialized are detailed in Exhibit 10.

These visits constituted a major asset for the winery in brand development and sales revenue. The Adobe itself, especially considering its contrastingly paradoxical design, created a one-of-a-kind and impactful experience by virtue of its differentiation from expected patterns. The human mind is designed to compare patterns, or discrepancies thereof (Ariely, 2010). The experiences at the Adobe were the primary contributor to the growth in sales and wine club membership acquisition (T. Bonomi \& P. Behan, personal communication, July 2, 2020).

Since the onset of the pandemic, the winery augmented its hospitality sanitation protocols to keep guests and staff safe. The "Visit Us" page on the website provided a list of tasting room protocols (see Exhibit 11 for details).

The Tasting Room Visitor Policy entailed various components designed for safety. Guests were asked to remain six feet apart and to wear a mask when entering, and until seated at the table with wine poured. Groups were limited to six and guests were asked not to make physical contact with staff. Other stipulations revolved around not visiting if one had showed any potential COVID-19 symptoms and the staff's right to refuse service if symptoms were observed. The measures aimed to add a level of comfort for the many consumers who were concerned with getting sick. However, many consumers were either mandated to remain at home or elected to do so on their own accord. The winery developed a virtual tasting to offer consumers a way to replicate the experience of visiting the Adobe from the comfort and safety of their own homes. The virtual tasting options offered on the website are detailed in Exhibit 12.

The tour and tasting experience included a virtual tour of the Adobe to begin and content depicting the vineyards of origin as guests were prompted to taste. The hosts conveyed passion for the wines and epicurean discovery with professional warmth (ThreeSticksWines, n.d.-a, n.d.-b).

\section{Marketing}

Three Sticks sought to create brand associations with congeniality, luxury, and passionate fun. The brand reinforced these associations throughout its touch points with consumers. Exhibit 13 details the focus of each touch point.

\section{Social media and brand created content}

Three Sticks was active on social media and had established a significant following. The presence on Facebook, Instagram, and Twitter is detailed in Exhibit 14.

The content was crafted to evoke brand associations the winery aimed to instill in consumers. The thematic focus of congeniality and passionate fun was conveyed with videos of varying length. Videos were centered in many cases around tasting, events, the estate vineyards, and winemaking process. Videos ranged from two to 34 minutes on Instagram's video platform, IGTV, and from under ten seconds to almost eight minutes on Facebook (ThreeSticksWines, n.d.a; ThreeSticksWines [@threestickswines],n.d.).

After the onset of COVID-19, the brand increased its social media activity. Notably, its online presence was leveraged to promote newly imagined virtual events, including concerts and discussions with chefs. The concert series was presented as "Three Sticks Together" and raised money for charity. Concerts were presented via Facebook Live and featured Bill Price as the wine-wielding master of ceremonies while Grammy award-winning musicians performed remotely. Between songs, Price took the floor and engaged the audience with wine and friendly conversation. In these breaks between sets, he updated the audience on the fundraising progress. The award-winning musical talent was recruited in part using Price's unique relationships and contacts. 


\section{Exhibit 10: Adobe Hospitality Experiences}

- Focused Tastings

\section{Taste of Three Sticks at the Adobe}

Taste through a guided, educational flight of our estate Chardonnay and Pinot Noirs. Learn about our historic Adobe home and our portfolio of Sonoma County vineyard sites during this private experience.

$\$ 50$ per person

- Dining Options - In Partnership with El Dorado Kitchen

\section{Food \& Wine Pairing}

Five of our favorite wines, each paired with small bites crafted just for Three Sticks. Monday-Friday only. Vegan and gluten-free options available.

$\$ 85$ per person

\section{Private Luncheon}

A three-course meal that includes five perfectly-paired wines. 4 person minimum, Monday-Friday only. Vegan and gluten-free options available.

$\$ 200$ per person

Source: ThreeSticksWines.com

\section{Exhibit 11: Tasting Room Protocols}

- Our Adobe staff and guests are required to wear face coverings in common areas. Guests may remove their masks while in their private tasting space. We have single-use masks for guests, available upon request.

- We have instituted touchless entry to the Adobe. Upon arrival, please call 707-996-3328 $\times 105$ and your host will greet your group.

- As always, we have secluded spaces throughout our property to ensure that your experience is solely yours. Each area is limited to one group per seating and will have a dedicated host to guide the experience. Tables, chairs, \& glassware are sanitized prior to guest arrival.

- Groups are limited to six or fewer people and scheduled to ensure limited interaction between groups.

- All surfaces, bathrooms, and communal spaces are sanitized after each use.

- Hand sanitizer is always readily available, as well as restrooms with hot water, soap, and single-use paper towels. We encourage frequent hand washing for staff and guests.

- All wine flights are pre-poured shortly before your appointment time and protected with glass coverings.

- Adobe management conducts daily wellness screenings with all hosts. Additionally, guests are asked to stay home if they are feeling unwell.

- Guests are asked to agree to our Tasting Room Visitor Policy upon requesting a reservation and will be advised of our protocol upon arrival.

- Adobe staff will maintain a $6 \mathrm{ft}$ distance from our guests and each other. Guests in the same group do not need to maintain that distance, but we do ask that everyone be mindful of other guests at the Adobe.

Source: ThreeSticksWine.com, July 2020

Exhibit 13: Brand Touch Point Focus

\begin{tabular}{|c|c|}
\hline Luxury & Congeniality, passion, \& fun \\
\hline Label & Social Media \\
\hline Website & Video Content \\
\hline Wine Tasting & Wine Host \\
\hline & Events \\
\hline
\end{tabular}

Source: Prepared by author from an interview conducted with Prema Behan, July 22, 2020.

\section{Philanthropy}

Price Family Vineyards, Three Sticks Wines, and Head High all contributed to philanthropic efforts at a generous rate with respect to the wine or any other sector. After Head High was founded in 2015, donations of over USD 48,000 apiece were made to the Sustainable Surf and Sonoma Valley Education Foundation that year. In 2017, Three Sticks 
Exhibit 12: Virtual Tasting Options

\begin{tabular}{|c|c|}
\hline Fall Release Tasting Kit & Taste of Three Sticks Fall Kit \\
\hline A selection of our newest Chardonnays and Pinots & An introduction pack of three wines \\
\hline Here's how our virtual tasting works: & Here's how our virtual tasting works: \\
\hline $\begin{array}{l}\text { We'll ship a selection of wines to your home (see below-no } \\
\text { substitutions, unfortunately!). Once you've received your kit, } \\
\text { our concierge will be in touch to schedule your virtual, at-home } \\
\text { tasting based on your preferred day and time. These will be } \\
\text { hosted via Zoom and will include a tour of our Adobe home } \\
\text { along with a guided tasting of the wines in your shipment. }\end{array}$ & $\begin{array}{l}\text { We'll ship a selection of wines to your home (see below-no } \\
\text { substitutions, unfortunately!). Once you've received your kit, } \\
\text { our concierge will be in touch to schedule your virtual at-home } \\
\text { tasting based on your preferred day and time. These will be } \\
\text { hosted via Zoom and will include a tour of our Adobe home } \\
\text { along with a guided tasting of the wines in your shipment. }\end{array}$ \\
\hline Wines included in your tasting kit: & Wines included in your tasting kit: \\
\hline $\begin{array}{l}2018 \text { Alana Vineyard Chardonnay } \\
2018 \text { Durell Vineyard Chardonnay } \\
\text { 2018 Durell Vineyard Pinot Noir } \\
2018 \text { William James Vineyard Pinot Noir } \\
2018 \text { Gap's Crown Vineyard Pinot Noir }\end{array}$ & $\begin{array}{l}2018 \text { Durell Vineyard Chardonnay } \\
2018 \text { Durell Vineyard Pinot Noir } \\
2018 \text { Gap's Crown Vineyard Pinot Noir } \\
\$ 200.00\end{array}$ \\
\hline$\$ 345.00$ & \\
\hline
\end{tabular}

Source: ThreeSticksWines.com.

Exhibit 14: Three Sticks Wines Social Media Presence as of August 3, 2020

\begin{tabular}{|c|c|c|c|c|c|}
\hline \multicolumn{2}{|c|}{ Facebook } & \multicolumn{2}{|c|}{ Instagram } & \multicolumn{2}{|c|}{ Twitter } \\
\hline Likes & 2,878 & Followers & 4,770 & Followers & 1,281 \\
\hline Follows & 3,145 & Following & 1,190 & Likes & 463 \\
\hline Check-Ins & 2,805 & Posts & 571 & Following & 607 \\
\hline Videos & 68 & Video (IGTV) & 7 & Tweets & 1,157 \\
\hline Rating & 5 of 5 with 50 ratings & & & & \\
\hline
\end{tabular}

Source: Three Stick's Facebook, Instagram, and Twitter accounts.

donated USD 50,000 for fire relief in response to a devastating season both locally and statewide. In 2018 Bill and Eva Price made several donations, including USD 50,000 to Challenge Success and USD 25,000 apiece to the Sonoma County Vintners, Summer Search, and Food Corps. In 2019, the Oahu Chapter of the Surfrider organization received a USD 3,000 donation. Approximately USD 25,000 apiece was again given to the Sonoma County Vintners, Summer Search, and Food Corps. Challenge Success again received USD 50,000 in 2019. Head High donated over USD 13,000 again to both to the Sustainable Surf and Sonoma Valley Education Foundations. In 2020, Three Sticks raised over USD 78,000 for Plus1/MusiCares and USD 20,000 for Sonoma Family Meal.

Three Sticks also made annual donations of wine experiences and packages of USD 1,000 to 2,500 in value. Specifically, these donations had benefited the following organizations: Red, White \& Snow, Line, Vine \& Dine (Emeril Lagasse Foundation), Signature Sonoma, Sun Valley Center for the Arts, Sonoma County Wine Auction, Meals on Wheels, The Guardsmen, Uncork for Hope, California Winemasters, and others (Papakhian, 2020).

\section{PRODUCTIONS AND SUPPLY CHAIN OPERATIONS}

\section{Organizational design}

Three Sticks Wines was a separate company owned by Price Family Vineyards. Three Sticks specifically had 21 fully dedicated employees, plus three employees which handled finance across the scope of PFV's operations. The organizational structure is illustrated in Exhibit 15.

Prema Behan, general manager of Three Sticks Wines, provided her assessment of current staffing levels relative to current and expected business needs. She explained: "We are likely overstaffed in (hospitality) at present. The eight employees are all working limited hours...some re-deployment has been made" (P. Behan, personal communication, July 22, 2020).

\section{Wine production}

Three Sticks produced approximately 10,000 9L cases of wine each year with limited variability by vintage. The wine was produced in a leased winemaking facility, within the Wine Country Industrial Park located in Sonoma. Grapes from both estate and outside vineyards were brought to the facility for processing. Three Sticks was comprised of exclu- 
ing placement and price alignment, as to avoid eroding the brand image and higher margin DTC effort (C. Mattson, per-

sonal communication, July 23, 2020).

\section{FUTURE OPPORTUNITIES}

\section{Digital brand building and sales}

Thomas Bonomi. Three Sticks could have considered enhancing its digital marketing efforts to build the brand. Building exposure could have added new consumers to the wine club or mailing lists, or even as one-time purchasers. Courting influ-
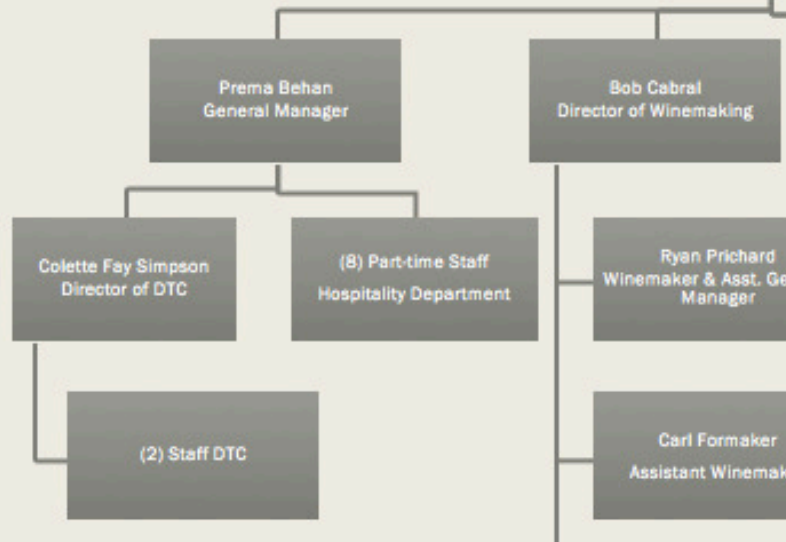
encers was another available tactic. Three Sticks could have analyzed and targeted specific influencers to attract and used thematic content designed to gain mention and approval from them. The influencers' approval would have referred their audiences to the brand and provided indepen-

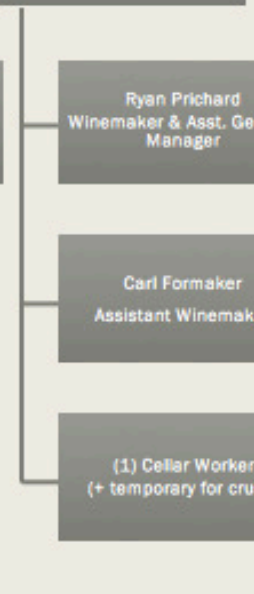

dent validation.

Co-promoting within a family of wineries and vineyards

ar The winery could create a tailored marketing plan for each vineyard individually that was not specific to Three Sticks. The vineyards were already named on bottlings from Kistler, Gary Farrell, and many outside producers. The marketing efforts of these wineries represented a significant advantage to building the vineyards' individual brands. Experiences could be designed for tasting or visiting the vineyards. Experience design could incorporate designated

Exhibit 15: Organizational Chart PFV \& Three Sticks Wines, 2020

*Circles signify members of PFV. Square boxes signify dedicated employees to Three Sticks Wines.

Source: Prepared by the author with information from multiple interviews with Three Sticks Wines.

sively estate grown grapes, whereas the Head High brand was made with fruit from both the estate and outside vineyards. Ten thousand 9L cases of Head High was also produced on average each vintage. Head High featured two wines, a Pinot Noir and Chardonnay, both from the Sonoma County appellation (T. Bonomi \& P. Behan, personal communication, July 2, 2020). The various bottlings of Three Sticks Wines are outlined in Exhibit 16.

\section{Route to market}

Three Sticks sold its wine in various venues and channels, with the Adobe hospitality program contributing most significantly. Wine was sold directly to the consumer, primarily via the Adobe tasting room, but also through the website and phone ordering. Approximately 65 percent of the production was allocated to sell DTC with the balance offered on the wholesale market. Three Sticks offered its wine to select on- and off-premise retailers in most major markets and many smaller ones across the country. The largest allocation was of the Price Family Estates Pinot Noir and the Durell Vineyard Chardonnay. Limited allocations of both Pinot Noir and Chardonnay from the Gap's Crown Vineyard were offered as well. The outside sales effort was guided within a framework of high brand standards regardlocations of physical beauty on the tour to take pictures and "selfies." Additionally, the concept allows consumers concerned about entering a confined space to be more comfortable.

If Gary Farrell or Kistler deemed it prudent to create vineyard tours of their own, the wineries could have directed guests to the same designated location for pictures. Visitors from the various wineries could thereby tag the vineyard itself in addition to the winery they visited.

One option was to directly co-promote with Kistler, Gary Farrell, and Head High. In theory, the combined strategic clout with both trade partners and the market would have been superior to what Three Sticks had enjoyed. The aggregate influence of marketing assets such as allocation, portfolio range, and multi-brand offers would likely have improved the positioning of Three Sticks Wines.

\section{Increased wholesale allocation and search for partnerships}

The winery could have considered increasing the allocation of wines to the wholesale market. This strategy would have effectively shifted more of the marketing burden to the distributors and their retail clients. Such a decision would have decreased margin, cost, and risk of throughput failure. The strategy would have entailed an increased risk of improper or negative brand perception given its reliance on partners to present the brand.

New partnerships with the "fourth tier" in the distribution system, alcohol delivery, could have been an effective means of moving some additional product through to the consumer. Such partnerships would likely have entailed 
Exhibit 16: Three Stick's Wine Portfolio

\begin{tabular}{|c|c|c|c|c|c|}
\hline \multicolumn{3}{|c|}{ Three Sticks Wines } & \multicolumn{3}{|c|}{ Casteñada by Three Sticks Wines } \\
\hline Grape & Bottling & Price & Grape & Bottling & Price \\
\hline \multirow{8}{*}{ Pinot Noir } & Price Family Estates & $\$ 65$ & Rosé & Sonoma Coast & $\$ 45$ \\
\hline & Walala Vineyard & $\$ 70$ & White Blend & Sonoma Valley & $\$ 40$ \\
\hline & One Sky Vineyard & $\$ 70$ & Red Blend & Durell Vineyard & $\$ 50$ \\
\hline & Durell Vineyard & $\$ 70$ & & & \\
\hline & Gap's Crown Vineyard & $\$ 70$ & & & \\
\hline & William James Vineyard & $\$ 70$ & & & \\
\hline & Cuvée Eva Marie, One Sky & $\$ 90$ & & & \\
\hline & Russian River Valley & $\$ 65$ & & & \\
\hline \multirow{5}{*}{ Chardonnay } & One Sky Vineyard & $\$ 55$ & & & \\
\hline & Alana Vineyard & $\$ 75$ & & & \\
\hline & Durell Vineyard & $\$ 60$ & & & \\
\hline & Durell Vineyard "Origin” & $\$ 55$ & & & \\
\hline & Gap's Crown Vineyard & $\$ 55$ & & & \\
\hline Pinot Blanc & Durell Vineyard & $\$ 50$ & & & \\
\hline
\end{tabular}

Source: Prepared by the author with information from multiple interviews with Three Sticks Wines.

heavily reduced margins which poses a risk to the market price and revenue.

\section{DECISION TIME}

After the first lockdown was lifted to allow for restricted operations, a resurgence in the virus prompted a second lockdown. Could Three Sticks sustain its growth by follow- ing the existing strategy? If not, what should the strategy have been? 


\section{References}

Ariely, D. (2010). Chapter 1 - The Truth About Relativity. In Predictably irrational: the hidden forces that shape our decisions (Revised and Expanded Edition, p. 23). HarperCollins.

Asimov, E. (2019, October 14). How Climate Change Impacts Wine. The New York Times. https://www.nyti mes.com/interactive/2019/10/14/dining/drinks/climat e-change-wine.html

Behan, P. (2020, July 22). [Interview by M. Coyne; Email].

Bonomi, T., \& Behan, P. (2020, July 2). [Interview by M. Coyne; Email].

California Association of Winegrape Growers, Wine Institute, \& California Sustainable Winegrowing Alliance. (2020). COVID-19 HARVEST PROTOCOLS WORKBOOK. https://www.sustainablewinegrowing.or g/amass/library/30/docs/COVID-19\%20Harvest\%20Pr otocols\%20Workbook\%207.7.2020.pdf

Ciatti Global Wine \& Grape Brokers. (2020). California Report, 3(7), 3.

Dawes, J. (2008). Regularities in buyer behaviour and brand performance: The case of Australian beer. Journal of Brand Management, 15(3), 198-208. http s://doi.org/10.1057/palgrave.bm.2550099

Desjardins, J. (2019, March 11). Chart: Most Millennials Have Less Than $\$ 1,000$ in Savings. Visual Capitalist. $\underline{\mathrm{h}}$ ttps://www.visualcapitalist.com/chart-most-millennia ls-less-1000-savings/

International Organisation of Vine \& Wine Intergovernmental Organisation. (2019). 2019 Statistical Report on World Vitiviniculture [Rep.]. htt p://oiv.int/public/medias/6782/oiv-2019-statistical-re port-on-world-vitiviniculture.pdf

Laube, J. (2011). \#1 of 2011: Kosta Brown Pinot Noir. WineSpectator.com. https://www.winespectator.com/ video/play/id/aYqC0B5M/title/1-of-2011-kosta-brow n-pinot-noir

Lombardo, C. (2020). Wineries in the US [Rep.]. IBIS World. https://my-ibisworld-com.sonoma.idm.oclc.or $\mathrm{g} /$ download/us/en/industry/289/7/0/pdf

Luckel, M. (2020, June 16). Ken Fulk Is Reimagining the Chrysler Building's Iconic Cloud Club.

Architecturaldigest.com. https://www.architecturaldig est.com/story/ken-fulk-is-reimagining-the-chrysler-b uildings-iconic-cloud-club

Mattson, C. (2020, July 23). [Interview by M. Coyne; Email].

McMillan, R. (2020). State of the US Wine Industry 2020 [Rep.]. Silicon Valley Bank Wine Division.
Mercer, C. (2019, July 2). Bordeaux winemakers allow new grapes to fight climate change. Decanter. http s://www.decanter.com/wine-news/bordeaux-new-win e-grapes-419730/

Ozgo, D. M. (2020). Annual Economic Briefing Support Tables-2019 [Rep.]. Distilled Spirits Council. https://w ww.distilledspirits.org/wp-content/uploads/2020/02/ Economic-Briefing-Support-Tables-2019.pdf

Papakhian, M. (2020, August 5). Philanthropy History.

Statistics - Wines Vines Analytics. (n.d.). Wines Vines Analytics. https://winesvinesanalytics.com/statistics/ winery/

Three Sticks. (n.d.-a). Bob Cabral Director of Winemaking. threestickswines.com. https://www.thre estickswines.com/team/bob-cabral/?noredirect=true

Three Sticks. (n.d.-b). History. threestickswines.com. htt ps://www.threestickswines.com/wp-content/uploads/ History-1.pdf

ThreeSticksWines. (n.d.-a). Home [YouTube Channel]. Retrieved July 5, 2020, from https://www.youtube.co m/user/ThreeSticksWines/featured

ThreeSticksWines. (n.d.-b). Home [Facebook page]. Facebook. Retrieved July 5, 2020, from https://www.fa cebook.com/threestickswines

ThreeSticksWines [@threestickswines]. (n.d.).Posts [Instagram profile]. Retrieved July 5, 2020, from http s://www.instagram.com/threestickswines/

Wine Communications Group. (2011, March 30). Classic Wines and Price Family Vineyards Name Tom Bonomi as President \& CFO of Classic Wines.

Winebusiness.com. https://www.winebusiness.com/pe ople/?go=getPeopleArticle \&dataId $=85700$

Wine Communications Group. (2016a, February 9). Head High Wines announces North Shore big wave surfer Andy St. Onge as brand ambassador. Winebusiness.com. https://www.winebusiness.com/ne ws $/$ ?go $=$ getArticle \&dataid $=164523$

Wine Communications Group. (2016b, April 19). Bill Price introduces Price Family Vineyards \& Estates. Winebusiness.com. https://www.winebusiness.com/ne wreleases/?go=getArticle \&dataId $=167765$

Wine Communications Group. (2020, June 30). Sonoma State University Releases Study on Economic Impact of COVID-19. Winebusiness.com. https://www.winebu $\underline{\text { siness.com/news/?go=getArticle \&dataId }=233088}$

Wines Vines Analytics. (2019, January 16). Total U.S. Wine Market Tops $\$ 70$ Billion. winebusiness.com. http s://www.winebusiness.com/news/?go=getArticle \&dat $\underline{\text { aId }=208385}$ 